\title{
Research on the effect of the size of the wall- hanging air-conditioner indoor unit on the indoor thermal comfort
}

Kuanbing Caozhu ( $\sim 2786459033 @ q q . c o m$ )

Xi'an University of Science and Technology

Changfa Ji

Xi'an University of Science and Technology

\section{Original Article}

Keywords: wall-hanging air-conditioner; size of indoor unit; comfort; numerical simulation

Posted Date: May 8th, 2020

DOI: https://doi.org/10.21203/rs.3.rs-27036/v1

License: (c) (i) This work is licensed under a Creative Commons Attribution 4.0 International License.

Read Full License 


\section{Abstract}

The geometrical dimension of the wall-hanging air-conditioner indoor unit affects the indoor thermal comfort. In this paper, fluent software is used and standard k-e two equation turbulent model is chosen to carry out the simulation of the indoor temperature field and flow field of six different sizes of the single wall-hanging indoor air-conditioner in the room. The temperature distribution, velocity distribution and PMV distribution of the plane which is $1.8 \mathrm{~m}$ from the ground are given. It can be known that under the condition of six kinds of sizes of the wall-hanging air-conditioner indoor unit, when the size of the airconditioner indoor unit is $0.4 \mathrm{~m} \times 0.2 \mathrm{~m} \times 0.2 \mathrm{~m}$, the temperature variation at the $\mathrm{z}=1.8 \mathrm{~m}$ section is relatively small, the temperature distribution is more uniform. When the size of the air-conditioner indoor unit is $0.5 \mathrm{~m} \times 0.2 \mathrm{~m} \times 0.2 \mathrm{~m}$, the temperature difference at the $\mathrm{z}=1.8 \mathrm{~m}$ section is relatively smaller, PMV is closest to 0 , and the thermal sensation is almost moderate. Therefore when the size of the airconditioner indoor unit is $0.5 \mathrm{~m} \times 0.2 \mathrm{~m} \times 0.2 \mathrm{~m}$, better indoor comfort can be achieved.

\section{Introduction}

As people's living standard improves, their demand for thermal comfort of the indoor environment is increasingly higher and higher. Thermal comfort is a feeling of people's physiology and psychology, which refers to a series of activities of the nervous system. These activities make people produce the feeling of pleasure psychologically[1]. The factors that affect the indoor comfort include: the position of the indoor air-conditioner, air supply angle, air supply parameters(air supply temperature, air supply velocity), air distribution modes, indoor heat source and so on. In literature [2], the effect of air distribution modes on the indoor air distribution was studied and the thermal field and flow field of the indoor air were analyzed. In literatures[3-5], the research on the effect of air supply angle on the indoor thermal field and flow field was conducted. On the basis of literature[3-5], the effect of the position of the indoor airconditioner on the indoor environment was studied in literature[6], in which the distribution of the indoor thermal field was mainly analyzed. In literature [7], the effect of air supply parameters on the indoor environment was taken into consideration based on literatures[3-5], and the distribution of the indoor thermal field and flow field was analyzed. In literature [8], the research of the effect of air supply parameters on the indoor environment was also carried out with more analysis of the distribution of indoor temperature field. The analysis of the distribution of the indoor thermal field was conducted in literature[9], in which the appropriate diversion plate angle was determined and the indoor temperature distribution was optimized.

In literatures mentioned above, the distribution of the indoor thermal field and flow field is mainly analyzed through the methods of numerical simulation and experiment. The effects of the installation position of indoor air conditioners, air supply angle, air supply parameters and air distribution modes on the indoor environment are studied, nevertheless, there is seldom research on the effect of the size of airconditioner indoor unit and the arrangement of multiple air-conditioner indoor units. In this paper, the effect of the size of wall-hanging air-conditioner indoor unit on the indoor thermal comfort is studied, with 
the distribution of the indoor thermal field and flow field analyzed and the evaluation index of thermal comfort PMV introduced.

\section{Analysis Of Numerical Simulation 2.1 Physics Model}

A simplified empty bedroom with a wall-hanging air-conditioner is adopted as the model in the paper in Fig. 1 as follows. The size of the room is $5 \mathrm{~m} \times 3 \mathrm{~m} \times 3 \mathrm{~m}$ (length*width*height), and the design working condition of the model is summer. The wall-hanging air-conditioner indoor unit is located at the position which is $2 \mathrm{~m}$ from the ground and $1 \mathrm{~m}$ from the left wall.

\subsection{Mathematics Model and Basic Assumption}

The application of computational fluid dynamics in the indoor environment is based on the discretization of the continuity equation, momentum conservation equation and energy conservation differential equation of in-compressible air and numerical analysis[10].The equations which need solving are continuity equation, momentum conservation equation and energy conservation equation. In this paper, the standard k-e two-equation model is used as the turbulent model, and the control volume method is employed to discretize the whole solution area. In order to simplify the problem, the assumptions that can be made include: (1) the air in the room is treated as the continuous in-compressible fluid; (2) both the flow process and heat transfer process in the room are steady, and the air flow is turbulent; (3) heat transfer in the room is convective heat transfer with no consideration of conduction and radiation heat transfer; (4) the room is sealed and there is no air leakage; (5) wall thickness is neglected in the indoor convective heat transfer; (6) the effect of heat source on the indoor environment is not considered.

\subsection{Settings of Solution Parameters and Boundary Conditions}

For control variate method is employed to carry out the research on the effect of the size of wall-hanging air-conditioner indoor unit on the indoor thermal environment, the design temperature of the indoor airconditioner in summer is chosen as $26^{\circ} \mathrm{C}$, the air supply temperature is set to $21^{\circ} \mathrm{C}$, and the temperature difference of air supply is $5^{\circ} \mathrm{C}$. It is determined that the mode of air supply in the room is air supply downwards and air return upwards. The cooling load is constant and the air supply volume is constant, As to the single wall-hanging air-conditioner, with the change in the size of the indoor unit, the air supply velocity also changes. Six kinds of sizes of wall-hanging air-conditioner indoor units are chosen for numerical calculation, which are listed in the Table 1 as follows 
Table 1

the size of air-conditioner indoor units and air supply velocity

\begin{tabular}{|c|c|c|c|c|c|}
\hline $\begin{array}{l}\text { working } \\
\text { condition }\end{array}$ & $\begin{array}{l}\text { size of indoor } \\
\text { unit }\end{array}$ & $\begin{array}{l}\text { air supply } \\
\text { velocity }\end{array}$ & $\begin{array}{l}\text { working } \\
\text { condition }\end{array}$ & $\begin{array}{l}\text { size of indoor } \\
\text { unit }\end{array}$ & $\begin{array}{l}\text { air supply } \\
\text { velocity }\end{array}$ \\
\hline 1 & $\begin{array}{l}0.4 \mathrm{~m} \times 0.2 \mathrm{~m} \times \\
0.2 \mathrm{~m}\end{array}$ & $3.75 \mathrm{~m} / \mathrm{s}$ & 4 & $\begin{array}{l}0.6 \mathrm{~m} \times 0.2 \mathrm{~m} \times \\
0.3 \mathrm{~m}\end{array}$ & $2.5 \mathrm{~m} / \mathrm{s}$ \\
\hline 2 & $\begin{array}{l}0.5 \mathrm{~m} \times 0.2 \mathrm{~m} \times \\
0.2 \mathrm{~m}\end{array}$ & $3 \mathrm{~m} / \mathrm{s}$ & 5 & $\begin{array}{l}0.5 \mathrm{~m} \times 0.25 \mathrm{~m} \times \\
0.4 \mathrm{~m}\end{array}$ & $2.4 \mathrm{~m} / \mathrm{s}$ \\
\hline 3 & $\begin{array}{l}0.45 \mathrm{~m} \times 0.25 \mathrm{~m} \times \\
0.2 \mathrm{~m}\end{array}$ & $2.67 \mathrm{~m} / \mathrm{s}$ & 6 & $\begin{array}{l}0.5 \mathrm{~m} \times 0.3 \mathrm{~m} \times \\
0.5 \mathrm{~m}\end{array}$ & $2 \mathrm{~m} / \mathrm{s}$ \\
\hline
\end{tabular}

Discrete parameters are the same under six working conditions. In order to gain a more accurate solution, the second order upwind scheme is used for momentum, energy, turbulent kinetic energy and turbulent dissipation rate, whose relaxation factors are set by default. They are $0.7,1,0.8,0.8$ respectively. Residuals of every quantity are set by default too, where the residual criterion of energy is $10^{-6}$ and the residual criterion of other terms is 0.001 . Since the air supply velocity is known and the flow is regarded as in-compressible flow, the boundary condition at the inlet is velocity inlet boundary condition, and the air supply temperature is $21^{\circ} \mathrm{C}$. For pressure and velocity at the outlet are not known, the outlet boundary condition is outflow boundary condition[11]. Walls of the room are all stationary walls without slip, whose boundary conditions are the boundary conditions of convective heat transfer, and the heat transfer coefficient and free stream temperature on the wall are $10 \mathrm{~W} /\left(\mathrm{m} 2{ }^{*} \mathrm{~K}\right)$ and $30^{\circ} \mathrm{C}$ respectively. Standard wall function is employed as the wall function.

\subsection{Division of the Mesh}

In order to gain the correct solution, meshes of high quality should be chosen. In the paper, hexahedral structured mesh is chosen here to discretize the whole room. The conditions that need to be satisfied are: (1) the minimum orthogonal quality is near to 1 ; (2) For the heat transfer of the indoor air is studied here, the hexahedron of the air-conditioner is not included in the calculation area, the mesh is divided only in the whole room[11]. The mesh diagram of the second working condition is shown in Fig. 2, and cell numbers of mesh under six working conditions are shown in Table 2.

Table 2

the number of grid cells for every working condition

\begin{tabular}{|llll|}
\hline working condition & cell numbers of meshes & working condition & cell numbers of meshes \\
\hline 1 & 359872 & 4 & 359712 \\
\hline 2 & 359840 & 5 & 359680 \\
3 & 359856 & 6 & 359600 \\
\hline
\end{tabular}

\section{Calculation Results And Analysis}


In this paper, the effect of the size of wall-hanging air-conditioner indoor unit on the indoor environment is studied. Control variate method is used for numerical calculation. The thermal field and flow field of the indoor air at the section $z=1.8 \mathrm{~m}$ are analyzed here, and the index PMV is used here to evaluate the indoor thermal comfort.

\subsection{Analysis of Temperature Distribution under Different Sizes of Air-Conditioner Indoor Units}

When the size of the air-conditioner indoor unit is $0.4 \mathrm{~m} \times 0.2 \mathrm{~m} \times 0.2 \mathrm{~m}, 0.5 \mathrm{~m} \times 0.2 \mathrm{~m} \times 0.2 \mathrm{~m}, 0.45 \mathrm{~m} \times$ $0.25 \mathrm{~m} \times 0.2 \mathrm{~m}, 0.6 \mathrm{~m} \times 0.2 \mathrm{~m} \times 0.3 \mathrm{~m}, 0.5 \mathrm{~m} \times 0.25 \mathrm{~m} \times 0.4 \mathrm{~m}, 0.5 \mathrm{~m} \times 0.3 \mathrm{~m} \times 0.5 \mathrm{~m}$, graphs of temperature distribution at the $z=1.8 \mathrm{~m}$ section are shown in Fig. 3 , and the line diagram of temperature difference which is the maximum temperature-minimum temperature at the $z=1.8 \mathrm{~m}$ section with the size of the air conditioner indoor unit is shown in Fig. 4.

(a) size of indoor unit is $0.5 \mathrm{~m} \times 0.2 \mathrm{~m} \times 0.2 \mathrm{~m}$ (b) size of indoor unit is $0.4 \mathrm{~m} \times 0.2 \mathrm{~m} \times 0.2 \mathrm{~m}$

(c) size of indoor unit is $0.45 \mathrm{~m} \times 0.25 \mathrm{~m} \times 0.2 \mathrm{~m}$ (d) size of indoor unit is $0.6 \mathrm{~m} \times 0.2 \mathrm{~m} \times 0.3 \mathrm{~m}$

(e) size of indoor unit is $0.5 \mathrm{~m} \times 0.25 \mathrm{~m} \times 0.4 \mathrm{~m}(\mathrm{f})$ size of indoor unit is $0.5 \mathrm{~m} \times 0.3 \mathrm{~m} \times 0.5 \mathrm{~m}$

Table 3

size of indoor unit and temperature difference at the section $\mathrm{z}=1.8 \mathrm{~m}$

\begin{tabular}{|ll|}
\hline size of indoor unit & temperature difference at the section $\mathrm{z}=1.8 \mathrm{~m}$ \\
\hline $0.4 \mathrm{~m} \times 0.2 \mathrm{~m} \times 0.2 \mathrm{~m}$ & 6.37631 \\
\hline $0.5 \mathrm{~m} \times 0.2 \mathrm{~m} \times 0.2 \mathrm{~m}$ & 6.43345 \\
\hline $0.45 \mathrm{~m} \times 0.25 \mathrm{~m} \times 0.2 \mathrm{~m}$ & 6.73145 \\
\hline $0.6 \mathrm{~m} \times 0.2 \mathrm{~m} \times 0.3 \mathrm{~m}$ & 6.44782 \\
\hline $0.5 \mathrm{~m} \times 0.25 \mathrm{~m} \times 0.4 \mathrm{~m}$ & 6.68985 \\
\hline $0.5 \mathrm{~m} \times 0.3 \mathrm{~m} \times 0.5 \mathrm{~m}$ & 6.83221 \\
\hline
\end{tabular}

It can be seen from Fig. 3 that temperature near the air supply vent of the air-conditioner indoor unit is lower. The further the air is from the air supply vent, the higher the temperature is. As can be seen from Fig. 4. Before the size of the indoor unit $0.6 \mathrm{~m} \times 0.2 \mathrm{~m} \times 0.3 \mathrm{~m}$, temperature difference at the section $\mathrm{z}=$ $1.8 \mathrm{~m}$ increases first and decreases then. After the size of the indoor unit $0.6 \mathrm{~m} \times 0.2 \mathrm{~m} \times 0.3 \mathrm{~m}$, there is a gradual increase in temperature difference at the $z=1.8 \mathrm{~m}$ section with the increase in the size of indoor unit. It can be seen from Table 3 that when the size of the air-conditioner indoor unit is $0.4 \mathrm{~m} \times 0.2 \mathrm{~m} \times$ $0.2 \mathrm{~m}$, temperature difference at the $\mathrm{z}=1.8 \mathrm{~m}$ section is $6.37631 \mathrm{~K}$; when the size of the air-conditioner indoor unit is $0.5 \mathrm{~m} \times 0.2 \mathrm{~m} \times 0.2 \mathrm{~m}$, temperature difference is $6.43345 \mathrm{~K}$; when the size of the airconditioner indoor unit is $0.45 \mathrm{~m} \times 0.25 \mathrm{~m} \times 0.2 \mathrm{~m}$, temperature difference is $6.73145 \mathrm{~K}$; when the size of the 
air-conditioner indoor unit is $0.6 \mathrm{~m} \times 0.2 \mathrm{~m} \times 0.3 \mathrm{~m}$, temperature difference is $6.44782 \mathrm{~K}$; when the size of the air-conditioner indoor unit is $0.5 \mathrm{~m} \times 0.25 \mathrm{~m} \times 0.4 \mathrm{~m}$, temperature difference is $6.68985 \mathrm{~K}$; when the size of the air-conditioner indoor unit is $0.5 \mathrm{~m} \times 0.3 \mathrm{~m} \times 0.5 \mathrm{~m}$, temperature difference is $6.83221 \mathrm{~K}$. By comparison, it can be seen that when the size of the air-conditioner indoor unit is $0.4 \mathrm{~m} \times 0.2 \mathrm{~m} \times 0.2 \mathrm{~m}$, temperature difference is smaller, thus temperature distribution is more uniform.

\subsection{Analysis of Velocity Distribution under Different Sizes of Air-Conditioner Indoor Units}

When the size of the air-conditioner indoor unit is $0.4 \mathrm{~m} \times 0.2 \mathrm{~m} \times 0.2 \mathrm{~m}, 0.5 \mathrm{~m} \times 0.2 \mathrm{~m} \times 0.2 \mathrm{~m}, 0.45 \mathrm{~m} \times$ $0.25 \mathrm{~m} \times 0.2 \mathrm{~m}, 0.6 \mathrm{~m} \times 0.2 \mathrm{~m} \times 0.3 \mathrm{~m}, 0.5 \mathrm{~m} \times 0.25 \mathrm{~m} \times 0.4 \mathrm{~m}, 0.5 \mathrm{~m} \times 0.3 \mathrm{~m} \times 0.5 \mathrm{~m}$, graphs of velocity distribution at the $z=1.8 \mathrm{~m}$ section are shown in Fig. 5 , and the line diagram of velocity difference which is the maximum velocity-minimum velocity at the $z=1.8 \mathrm{~m}$ section with the size of the air conditioner indoor unit is shown in Fig. 6.

(a) size of indoor unit is $0.5 \mathrm{~m} \times 0.2 \mathrm{~m} \times 0.2 \mathrm{~m}$ (b) size of indoor unit is $0.4 \mathrm{~m} \times 0.2 \mathrm{~m} \times 0.2 \mathrm{~m}$

(c) size of indoor unit is $0.45 \mathrm{~m} \times 0.25 \mathrm{~m} \times 0.2 \mathrm{~m}$ (d) size of indoor unit is $0.6 \mathrm{~m} \times 0.2 \mathrm{~m} \times 0.3 \mathrm{~m}$

(e) size of indoor unit is $0.5 \mathrm{~m} \times 0.25 \mathrm{~m} \times 0.4 \mathrm{~m}$ (f) size of indoor unit is $0.5 \mathrm{~m} \times 0.3 \mathrm{~m} \times 0.5 \mathrm{~m}$

Table 4

size of indoor unit and velocity difference at the section $z=1.8 \mathrm{~m}$

\begin{tabular}{|ll|}
\hline size of indoor unit & velocity difference at the section $\mathbf{z}=1.8 \mathrm{~m}$ \\
\hline $0.4 \mathrm{~m} \times 0.2 \mathrm{~m} \times 0.2 \mathrm{~m}$ & 3.75634603 \\
\hline $0.5 \mathrm{~m} \times 0.2 \mathrm{~m} \times 0.2 \mathrm{~m}$ & 2.98163298 \\
\hline $0.45 \mathrm{~m} \times 0.25 \mathrm{~m} \times 0.2 \mathrm{~m}$ & 2.67431716 \\
\hline $0.6 \mathrm{~m} \times 0.2 \mathrm{~m} \times 0.3 \mathrm{~m}$ & 2.4910859 \\
\hline $0.5 \mathrm{~m} \times 0.25 \mathrm{~m} \times 0.4 \mathrm{~m}$ & 2.38639246 \\
\hline $0.5 \mathrm{~m} \times 0.3 \mathrm{~m} \times 0.5 \mathrm{~m}$ & 1.98909223 \\
\hline
\end{tabular}

It can be seen from Fig. 5 that velocity near the air supply vent of air-conditioner indoor unit is larger. When the air is away from the air supply vent, there is a more obvious decrease in velocity. In the indoor activity area, there are local areas where velocity is low. From Fig. 6 , it can be found that with the increase in the size of the air-conditioner indoor unit, the velocity difference at the $z=1.8 \mathrm{~m}$ section gradually decreases. That is, the larger the area of air supply vent, the smaller the velocity difference is. It can be seen from Table 4 that when the size of the air-conditioner indoor unit is $0.4 \mathrm{~m} \times 0.2 \mathrm{~m} \times 0.2 \mathrm{~m}$, velocity difference is $3.75634603 \mathrm{~m} / \mathrm{s}$; when the size of the air-conditioner indoor unit is $0.5 \mathrm{~m} \times 0.2 \mathrm{~m} \times 0.2 \mathrm{~m}$, velocity difference is $2.98163298 \mathrm{~m} / \mathrm{s}$; when the size of the air-conditioner indoor unit is $0.45 \mathrm{~m} \times 0.25 \mathrm{~m} \times$ 
$0.2 \mathrm{~m}$, velocity difference is $2.67431716 \mathrm{~m} / \mathrm{s}$; when the size of the air-conditioner indoor unit is $0.6 \mathrm{~m} \times$ $0.2 \mathrm{~m} \times 0.3 \mathrm{~m}$, velocity difference is $2.4910859 \mathrm{~m} / \mathrm{s}$; when the size of the air-conditioner indoor unit is $0.5 \mathrm{~m} \times 0.25 \mathrm{~m} \times 0.4 \mathrm{~m}$, velocity difference is $2.38639246 \mathrm{~m} / \mathrm{s}$; when the size of the air-conditioner indoor unit is $0.5 \mathrm{~m} \times 0.3 \mathrm{~m} \times 0.5 \mathrm{~m}$, velocity difference is $1.98909223 \mathrm{~m} / \mathrm{s}$. Velocity difference is smaller when the size of the air-conditioner indoor unit is $0.5 \mathrm{~m} \times 0.3 \mathrm{~m} \times 0.5 \mathrm{~m}$, so velocity distribution is more uniform.

\subsection{Analysis of PMV under Different Sizes of Air-Conditioner Indoor Units}

Temperature and velocity are two main factors which affect the indoor thermal comfort, but they are not used to evaluate the indoor thermal comfort. In order to evaluate it effectively, the important index- PMV needs to be introduced. PMV is graded by seven grades ${ }^{[12]}$, as is shown in Table 5. When the size of the air-conditioner indoor unit is $0.4 \mathrm{~m} \times 0.2 \mathrm{~m} \times 0.2 \mathrm{~m}, 0.5 \mathrm{~m} \times 0.2 \mathrm{~m} \times 0.2 \mathrm{~m}, 0.45 \mathrm{~m} \times 0.25 \mathrm{~m} \times 0.2 \mathrm{~m}, 0.6 \mathrm{~m} \times$ $0.2 \mathrm{~m} \times 0.3 \mathrm{~m}, 0.5 \mathrm{~m} \times 0.25 \mathrm{~m} \times 0.4 \mathrm{~m}, 0.5 \mathrm{~m} \times 0.3 \mathrm{~m} \times 0.5 \mathrm{~m}$, the average PMV at the $\mathrm{z}=1.8 \mathrm{~m}$ section calculated with fluent software is shown in Table 6.

Table 5

PMV thermal sensation scale

\begin{tabular}{|llllllll|}
\hline thermal sensation & cold & cool & slightly cool & moderate & slightly warm & warm & hot \\
\hline PMV & -3 & -2 & -1 & 0 & +1 & +2 & +3 \\
\hline
\end{tabular}

Table 6

PMV at the $z=1.8 \mathrm{~m}$ section under six different sizes of air-conditioner indoor unit

\begin{tabular}{|l|l|}
\hline sizes of indoor unit & PMV \\
\hline $0.4 \mathrm{~m} \times 0.2 \mathrm{~m} \times 0.2 \mathrm{~m}$ & 0.159429 \\
\hline $0.5 \mathrm{~m} \times 0.2 \mathrm{~m} \times 0.2 \mathrm{~m}$ & 0.146205 \\
\hline $0.45 \mathrm{~m} \times 0.25 \mathrm{~m} \times 0.2 \mathrm{~m}$ & 0.238195 \\
\hline $0.6 \mathrm{~m} \times 0.2 \mathrm{~m} \times 0.3 \mathrm{~m}$ & 0.15811349 \\
\hline $0.5 \mathrm{~m} \times 0.25 \mathrm{~m} \times 0.4 \mathrm{~m}$ & 0.23878027 \\
$0.5 \mathrm{~m} \times 0.3 \mathrm{~m} \times 0.5 \mathrm{~m}$ & 0.29167604 \\
\hline $\begin{array}{l}\text { It can be seen from Table } 6 \text { that for the six different sizes of indoor unit, PMV ranges from } 0-0.5 \text {, with } \\
\text { nobody feeling cold or hot. When the size of the air-conditioner indoor unit is } 0.5 \mathrm{~m} \times 0.2 \mathrm{~m} \times 0.2 \mathrm{~m},\end{array}$ \\
$\begin{array}{l}\text { PMV at the } z=1.8 \mathrm{~m} \text { section is smallest, which is closest to } 0 \text {, and thermal sensation is almost } \\
\text { moderate. Thus when the size of the air-conditioner indoor unit is } 0.5 \mathrm{~m} \times 0.2 \mathrm{~m} \times 0.2 \mathrm{~m} \text {, better indoor } \\
\text { comfort can be achieved. }\end{array}$ \\
\hline
\end{tabular}

\section{Conclusions}

The research on the temperature distribution, velocity distribution and PMV distribution at the $z=1.8 \mathrm{~m}$ section under six different sizes of wall-hanging air-conditioner indoor unit is carried out through the 
method of numerical simulation. Conclusions are as follows

(1) Under six different sizes of wall-hanging air-conditioner indoor unit, temperature in the activity area of the room is close to the indoor air-conditioning design temperature in summer. When the size of the airconditioner indoor unit is $0.4 \mathrm{~m} \times 0.2 \mathrm{~m} \times 0.2 \mathrm{~m}$, temperature difference is smaller, which is $6.37631 \mathrm{~K}$. Thus the indoor temperature distribution is more uniform.

(2) When the size of the air-conditioner indoor unit is $0.5 \mathrm{~m} \times 0.3 \mathrm{~m} \times 0.5 \mathrm{~m}$, velocity difference at the $z=1.8 \mathrm{~m}$ section is smallest, which is $1.98909223 \mathrm{~m} / \mathrm{s}$. Thus the velocity distribution is more uniform.

(3) When the size of the air-conditioner indoor unit is $0.5 \mathrm{~m} \times 0.2 \mathrm{~m} \times 0.2 \mathrm{~m}, \mathrm{PMV}$ at the $\mathrm{z}=1.8 \mathrm{~m}$ section is closest to 0 , and thermal sensation is almost moderate. Thus when the size of the air-conditioner indoor unit is $0.5 \mathrm{~m} \times 0.2 \mathrm{~m} \times 0.2 \mathrm{~m}$, better indoor comfort can be achieved.

(4)Although when the size of the air-conditioner indoor unit is $0.5 \mathrm{~m} \times 0.2 \mathrm{~m} \times 0.2 \mathrm{~m}$, the velocity difference is larger, the indoor temperature distribution is relatively smaller, and PMV at the $z=1.8 \mathrm{~m}$ section is closest to 0 . Thus it is more suitable that the size of the air-conditioner indoor unit is chosen as $0.5 \mathrm{~m} \times 0.2 \mathrm{~m} \times 0.2 \mathrm{~m}$.

\section{Declarations}

\section{Availability of data and materials}

1: Here, the six different sizes of the single wall-hanging indoor air-conditioner are chosen at random, which is to carry out the research on the effect of them on the indoor thermal comfort. Six different sizes of the single wall-hanging indoor air-conditioner are $0.4 \mathrm{~m} \times 0.2 \mathrm{~m} \times 0.2 \mathrm{~m}$, $0.5 \mathrm{~m} \times 0.2 \mathrm{~m} \times 0.2 \mathrm{~m}, 0.45 \mathrm{~m} \times 0.25 \mathrm{~m} \times 0.2 \mathrm{~m}, 0.6 \mathrm{~m} \times 0.2 \mathrm{~m} \times 0.3 \mathrm{~m}, 0.5 \mathrm{~m} \times 0.25 \mathrm{~m} \times 0.4 \mathrm{~m}, 0.5 \mathrm{~m} \times 0.3 \mathrm{~m} \times 0.5 \mathrm{~m}$. It is believed by medical experts that setting the design temperature of the indoor air-conditioner to $26^{\circ} \mathrm{C}$ can help save energy. And from the point of health, it is also the best temperature which can make you feel comfortable and hard to get sick, therefore the design temperature of the indoor air-conditioner in summer is chosen as $26^{\circ} \mathrm{C}$. Here the air supply temperature is set to $21^{\circ} \mathrm{C}$. According to literature 10 , the air supply temperature is the difference between the design temperature of the indoor air-conditioner and the air supply temperature difference, so the air supply temperature difference is the design temperature of the indoor air-conditioner subtracts air supply temperature, which is $5^{\circ} \mathrm{C}$. As for rooms, the recommended velocity of air supply inlet is $2.5-3.8 \mathrm{~m} / \mathrm{s}$. Thus when the size of air-conditioner indoor unit is $0.5 \mathrm{~m} \times 0.2 \mathrm{~m} \times 0.2 \mathrm{~m}$, the air supply velocity is set to $3 \mathrm{~m} / \mathrm{s}$, and the air supply volume rate is air supply velocity times the area of air supply vent. Cold air enters from the bottom of the air-conditioner indoor unit, thus for the size of air-conditioner indoor unit $0.5 \mathrm{~m} \times 0.2 \mathrm{~m} \times 0.2 \mathrm{~m}$, the area of air supply vent is $0.5 \times 0.2=0.1 \mathrm{~m}^{2}$, and the air supply volume rate is $0.3 \mathrm{~m}^{3} / \mathrm{s}$. For the specific room, the indoor cooling load and the air supply volume rate are constant, thus no matter what the size of air-conditioner indoor unit is, the air supply volume rate is kept unchanged at $0.3 \mathrm{~m}^{3} / \mathrm{s}$. For the other five sizes of air-conditioner indoor unit0. $4 m \times 0.2 m \times 0.2 m, 0.45 m \times 0.25 m \times 0.2 m, 0.6 m \times 0.2 m \times 0.3 m, 0.5 m \times 0.25 m \times 0.4 m, 0.5 m \times 0.3 m \times 0.5 m$, their 
areas of air supply vent are $0.08 \mathrm{~m}^{2}, 0.1125 \mathrm{~m}^{2}, 0.12 \mathrm{~m}^{2}, 0.125 \mathrm{~m}^{2}, 0.15 \mathrm{~m}^{2}$ respectively, thus the air supply velocity of the other five working conditions is $3.75 \mathrm{~m} / \mathrm{s}, 2.67 \mathrm{~m} / \mathrm{s}, 2.5 \mathrm{~m} / \mathrm{s}, 2.4 \mathrm{~m} / \mathrm{s}, 2 \mathrm{~m} / \mathrm{s}$ respectively. The air supply velocity under the six working conditions is listed in the Table 1 in my paper.

2: Numbers of grid cells under the six working conditions can be observed in fluent software. After the fluent software is started, the numbers of grid cells under the six working conditions can be known through the command "Mesh-Info--Size", which are listed in the Table 2 in my paper.

3: After the calculation of numerical simulation is complete, the post-processing operation is carried out. The cases and data under the six working conditions can be imported into the post-processing software--Tecplot through the command "File-Load Data Files". The height of human activity area from the ground is $1.7-1.9 \mathrm{~m}$, and $\mathrm{z}$ axis direction is height direction. The slice $\mathrm{z}=1.8 \mathrm{~m}$ is created here to carry out the research on the temperature distribution and velocity distribution. In Tecplot software, $z=1.8 \mathrm{~m}$ slice is created through several steps. First, click the "Slices" item under "Show derived objects" ; Second, proceed with the command "Plot-Slices", and the "Slice Details" appears. Choose the "Definition" item, and set the "Slice location" to $z$ planes, whose value is 1.8; At last, execute the command "Data--Extract-Current Slices". Thus the slice $z=1.8 \mathrm{~m}$ is created. After creating $z=1.8 \mathrm{~m}$ slice, choose the "Contour" item under "Show zone layers", click the "Details" item next to the "Contour" item, choose the Temperature variable. Besides, click the "Zone Style" below the "Show zone layers", in which only the zone where the " $z=1.8 \mathrm{~m}$ " slice is activated, choose the "Contour" item, and the "Contour Type" is set as "Lines and flood". Close the "Zone Style", click the "Details" item next to the "Contour" item, and the "Contour \& MultiColoring Details" appears. Choose the "Labels" item, click "Show labels" "Contour value" by turn. Then the temperature value on the $z=1.8 \mathrm{~m}$ slice under the six working conditions in the Fig. 3 of my paper can be observed. After observing the temperature value under the six working conditions, the conclusion that temperature near the air-supply vent of the air-conditioner indoor unit is lower. The further the air is from the air supply vent, the higher the temperature is can be drawn in my paper.

4: The slice $z=1.8 \mathrm{~m}$ has been created in the post-processing software--Tecplot. And velocity distribution on the $z=1.8 \mathrm{~m}$ slice can be displayed. Before it, velocity magnitude must be defined in the Tecplot software by executing the command"Data--Alter-Specify Equations". Then "Specify Equations" appears, in which the formula " $\{$ velocity magnitude $\}=s q r t(V 5 * V 5+V 6 * V 6+V 7 * V 7)$ can be entered, where $\mathrm{V} 5$ represents velocity in the $\mathrm{X}$ direction; $\mathrm{V} 6$ represents velocity in the $\mathrm{Y}$ direction and $\mathrm{V} 7$ represents velocity in the $Z$ direction. After doing so, the velocity magnitude has been defined.Then click the "Details" item next to the "Contour" item, and choose the variable "velocity magnitude". Besides, click the "Zone Style" below the "Show zone layers", in which only the zone where the " $z=1.8 \mathrm{~m}$ " slice is activated, choose the "Contour" item, and the"Contour Type" is set as "Lines and flood". Click the "Details" item next to the "Contour" item in the "Show zone layers", and the "Contour \& Multi-Coloring Details" appears. Choose the "Labels" item, click "Show labels" and "Contour value" by turn. Then the velocity value on the $z=1.8 \mathrm{~m}$ slice under the six working conditions in the Fig. 5 of my paper can be observed. After observing the velocity value under the six working conditions, the conclusion that velocity near the air supply vent of airconditioner indoor unit is larger. When the air is away from the air supply vent, there is a more obvious 
decrease in velocity. In the indoor activity area, there are local areas where velocity is low can be drawn in my paper.

5: The temperature difference on the $z=1.8 \mathrm{~m}$ slice is the maximum temperature subtracts the minimum temperature. The maximum temperature and the minimum temperature on the $\mathrm{z}=1.8 \mathrm{~m}$ slice can be calculated in the fluent CFD software through the command "Report-Result Reports-Surface Integrals", choose the Surface " $z=1.8 \mathrm{~m}$ ", the "Report Type" and click compute. The maximum temperature and the minimum temperature on the $z=1.8 \mathrm{~m}$ slice will be known. After it, the temperature difference can be calculated. The result of temperature difference on the $z=1.8 \mathrm{~m}$ slice under the six working conditions is listed in the Table 3 in my paper.

6: The velocity difference on the $z=1.8 \mathrm{~m}$ slice is the maximum velocity subtracts the minimum velocity. The maximum velocity and the minimum velocity on the $z=1.8 \mathrm{~m}$ slice can be calculated in the fluent CFD software through the command "Report-Result Reports-Surface Integrals", choose the Surface " $z=1.8 \mathrm{~m}$ ", the "Report Type" and click compute. The maximum velocity and the minimum velocity on the $z=1.8 \mathrm{~m}$ slice will be known. Then the velocity difference can be known. The result of velocity difference on the $z=1.8 \mathrm{~m}$ slice under the six working conditions is listed in the Table 4 in my paper.

7:The PMV(Predicted Mean Vote) can be defined by the formula in the reference 12 of my paper,which is $1.279+0.00293 \times T_{a}-16.967 \times v^{0.5}+3.618 \times v+0.498 \times v^{0.5} \times T_{a}$. The formula can be defined in the fluent CFD software through the command “Define-Custom Field Functions".After the definition of PMV is complete, the PMV value on the $z=1.8 \mathrm{~m}$ slice can be calculated in the fluent CFD software through the command "Report--Result Reports-Surface Integrals", choose the Surface " $z=1.8 \mathrm{~m}$ ", the "Facet Average" is chosen as the "Report Type" and then click compute. Thus the PMV value on the $z=1.8 \mathrm{~m}$ slice under the six working conditions can be known, which is listed in the Table 6 in my paper.

\section{Competing interests Not applicable}

\section{Funding Not applicable}

\section{Authors' contributions}

The first author Kuanbing Caozhu was responsible for the writing of the manuscript, and the second author Changfa Ji gave the first author some advice on how to revise the manuscript, and the first author made corrections several times according to what he said. All authors contributed equally to the writing of the paper. 


\section{References}

1. Zhou Jing, Li Yi. Numerical analysis of the effect of air supply velocity on the environment in the room with air-conditioner in winter [J]. Journal of Water Conservancy and Construction Engineering, 2014, 12(1):157-160

2. Zhai Dahai, Zhao Jinhui, Zhang lijuan. Numerical Simulation of Air Flow Field Distribution in The Room Equipped With Air-Conditioners [J].Energy Saving Technology, 2013,31(5): 420-425

3. Li Yang,Yu Wenhong, Wang Fulin. Numerical Simulation of Thermal Environment in the Office Equipped With Cabinet Air Conditioner based on Airpak Software[J].Journal of Northern University of Technology,2017,29(2):122-129

4. Yang Hua, Cao Lei, Jin Fengyun. Research on the Dynamic Simulation of the Effect of the Air Supply Angle of Displacement Ventilation on the Indoor Environment.[J].2018,47(4):42-49

5. Yin Guihua, Peng Xiaoyong, Zuo Zhenhai. Numerical Analysis of the Effect of Air Supply Angle of the Indoor Unit of Cabinet Air-Conditioner on the Indoor Thermal Comfort[J].Refrigeration and AirConditioning,2009,23(2):114-118

6. Zhang Zhiyu, Xue Bing, Kong XiangLing et al. The Research on the Numerical Simulation of the Effect of the Installation Position of Air-Conditioners and Air Supply Angle on Indoor Heat Transfer. [J].Fluid Machinery,2017,45(8):73-77

7. Peng Qian, Huang Jiwen, Liu Jinwu et al. Research on the Effect of Air Supply Parameters of AirConditioner in the Bus on the Indoor Flow Field.[J].Refrigeration and AirConditioning[J].2016,30(6):716d-719

8. Yang Mei, Nan Xiaohong, Chen Xiaohui. Experimental research on the effect of air supply parameters on the indoor temperature field in summer[J]. Journal of Guangzhou University(Natural Science Edition),2010,9(3):71-75

9. Shi Jianrong, Meng Qingguo, LiXiuli et al. The Effect of the Angle of Guide Plates of Air Conditioners on the Temperature of Indoor Air[J]. Chemical Equipment Technology, 2017,38(4):28-30

10. Wang Siping, Zhang Jing, Wang Hongwei. The effect of air supply velocity on the indoor thermal comfort[J]. Journal of Shenyang University of Architecture(Natural Science Edition), 2010,26(1):166170

11. Hu Renxi, Kang Shiting. Fluent 16.0 Flow Field Analysis from Introduction to Proficiency [M].Beijing:Machinery Industry Press,2016

12. Chen Guang, Wang Dongwei, Dai Xin et al. Research on the effect of indoor thermal comfort with displacement ventilation[J]. Refrigeration, Air-conditioning and Electrical machinery, 2008,20(3):2327

\section{Figures}




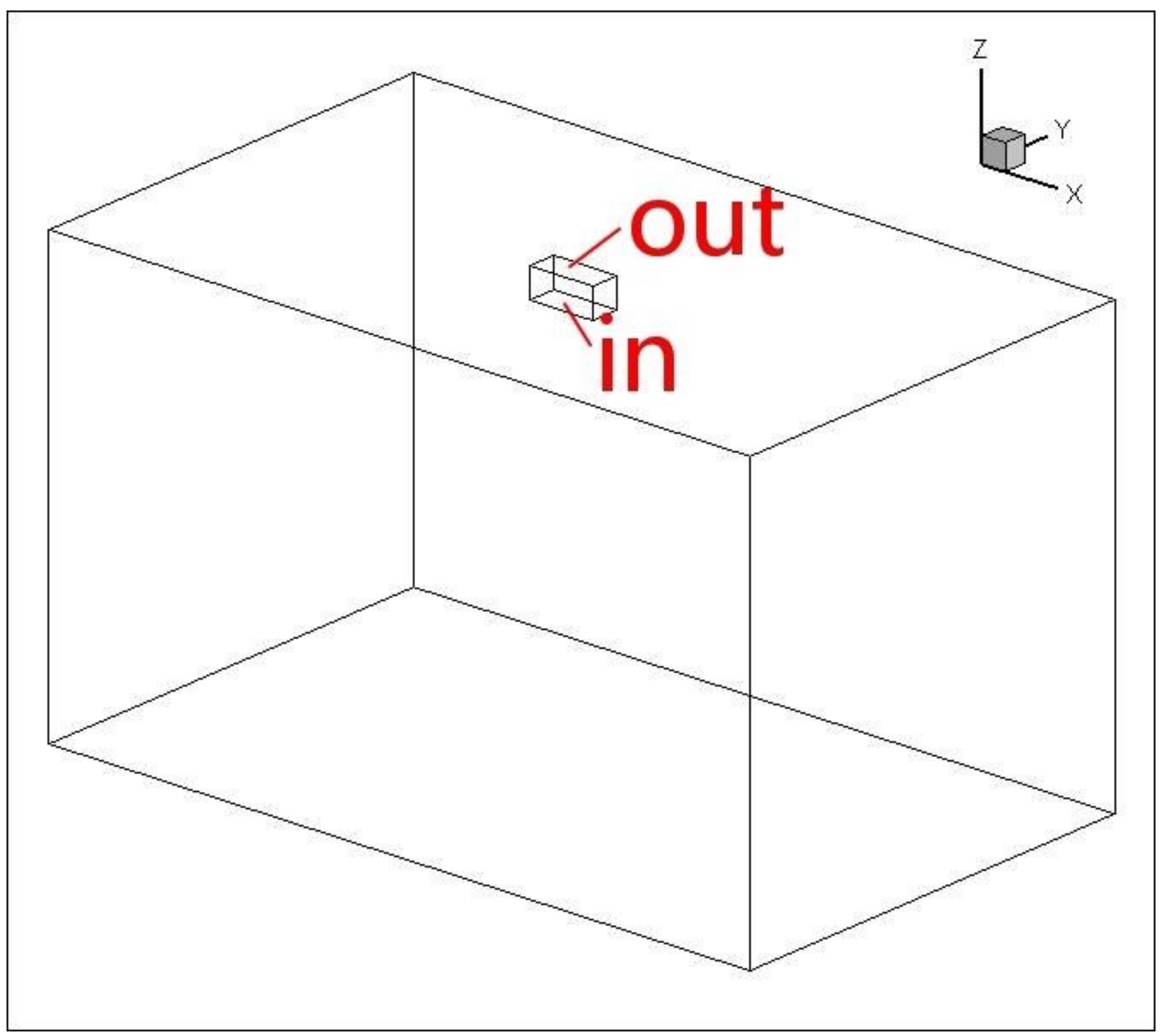

Figure 1

the simplified diagram of the room with wall-hanging air conditioner

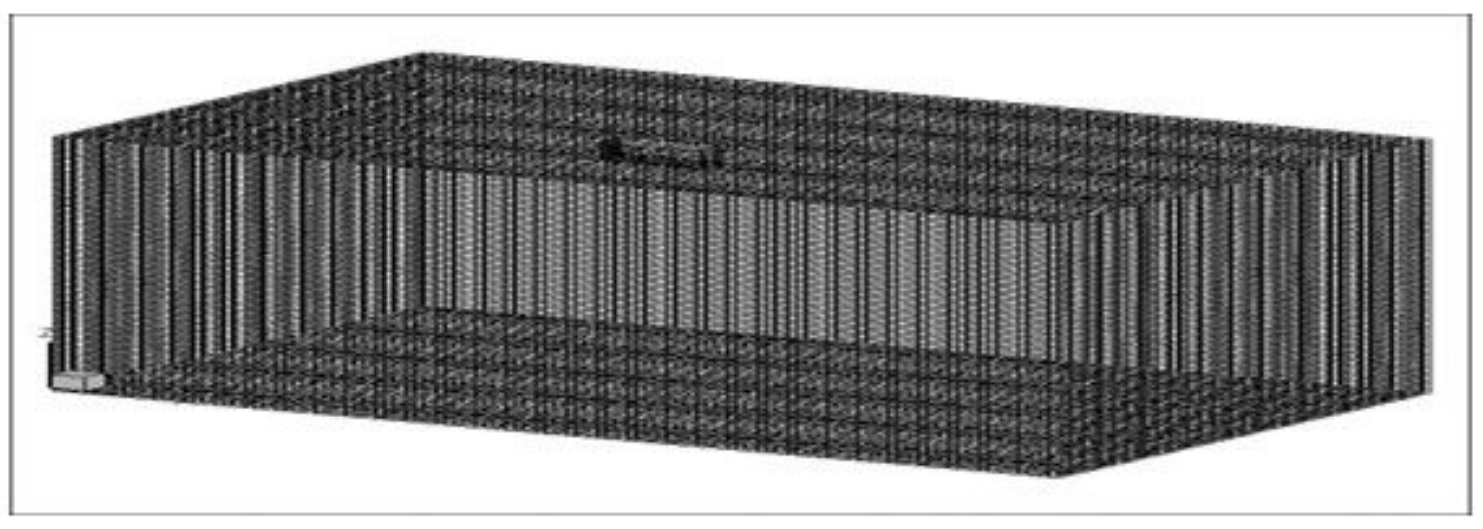

Figure 2 
the mesh diagram of the room with wall-hanging air-conditioner indoor unit
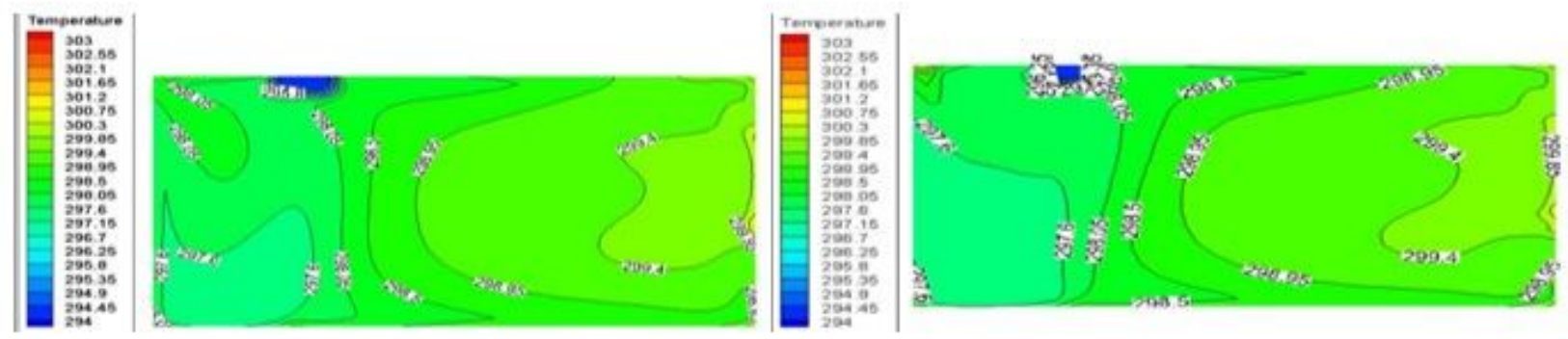

(a) size of indoor unit is $0.5 \mathrm{~m} \times 0.2 \mathrm{~m} \times 0.2 \mathrm{~m}$

(b) size of indoor unit is $0.4 \mathrm{~m} \times 0.2 \mathrm{~m} \times 0.2 \mathrm{~m}$
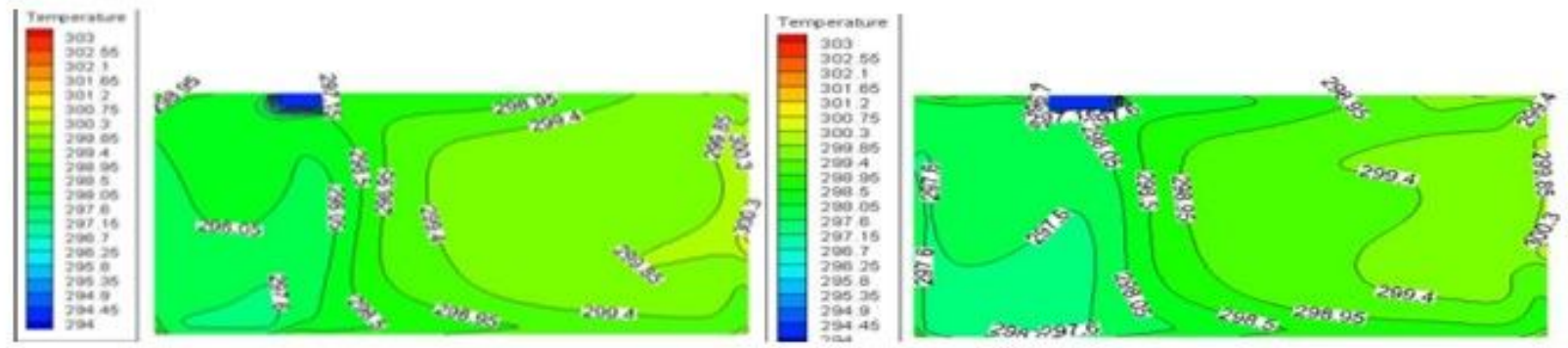

(c) size of indoor unit is $0.45 \mathrm{~m} \times 0.25 \mathrm{~m} \times 0.2 \mathrm{~m}$

(d) size of indoor unit is $0.6 \mathrm{~m} \times 0.2 \mathrm{~m} \times 0.3 \mathrm{~m}$
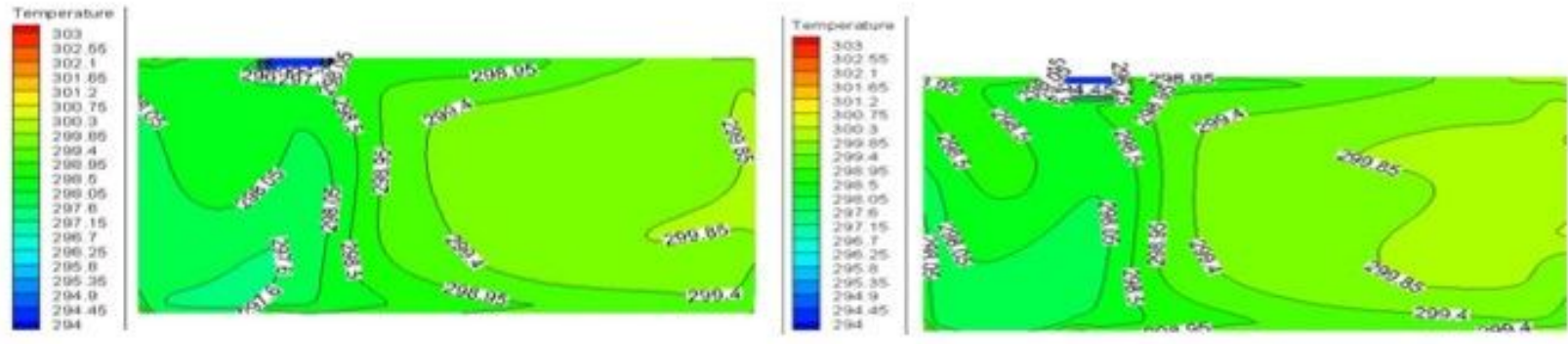

(e) size of indoor unit is $0.5 \mathrm{~m} \times 0.25 \mathrm{~m} \times 0.4 \mathrm{~m}$

(f) size of indoor unit is $0.5 \mathrm{~m} \times 0.3 \mathrm{~m} \times 0.5 \mathrm{~m}$

\section{Figure 3}

cloud pictures of temperature distribution at the section $z=1.8 \mathrm{~m}$ 


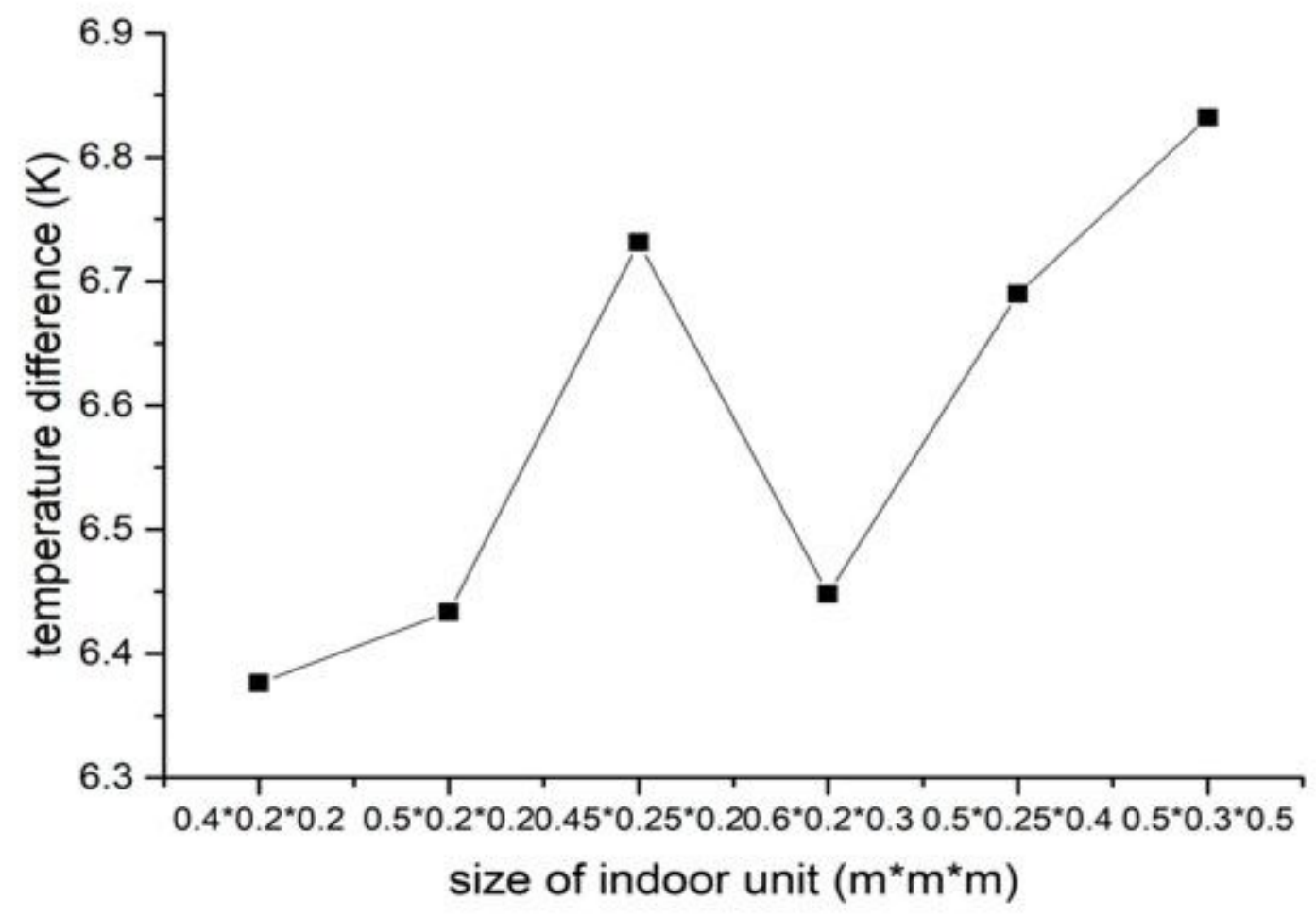

Figure 4

line diagram of temperature difference at the section $z=1.8 m$ 


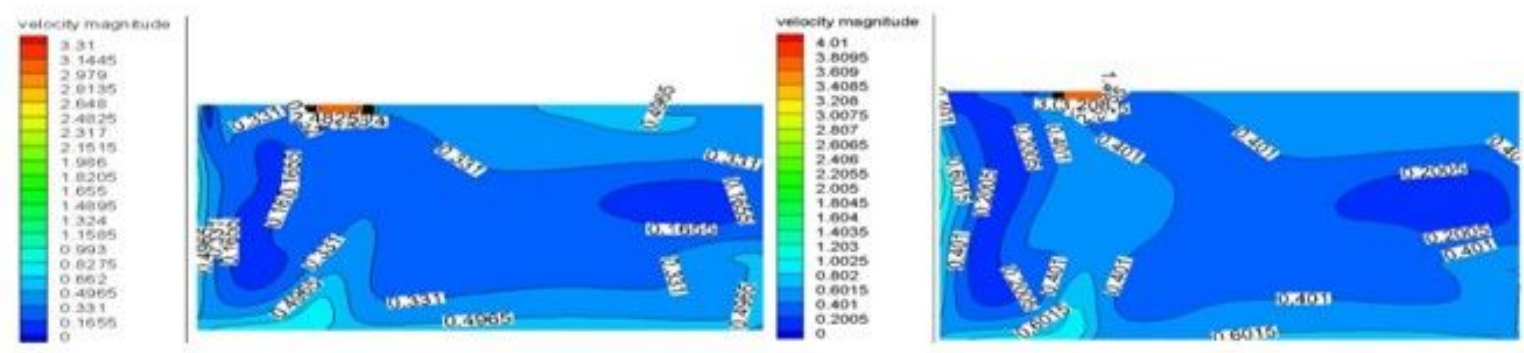

(a) size of indoor unit is $0.5 \mathrm{~m} \times 0.2 \mathrm{~m} \times 0.2 \mathrm{~m}$

(b) size of indoor unit is $0.4 \mathrm{~m} \times 0.2 \mathrm{~m} \times 0.2 \mathrm{~m}$
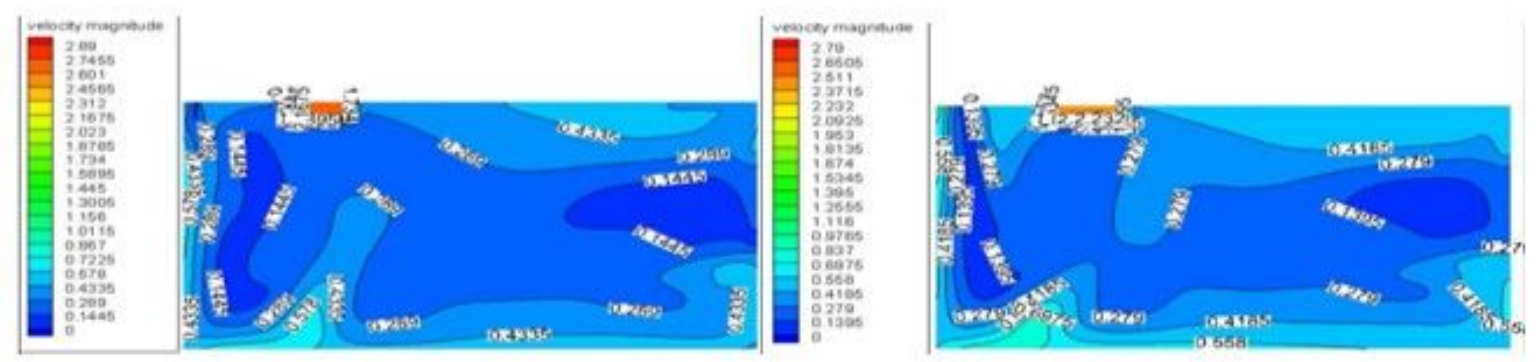

(c) size of indoor unit is $0.45 \mathrm{~m} \times 0.25 \mathrm{~m} \times 0.2 \mathrm{~m}$

(d) size of indoor unit is $0.6 \mathrm{~m} \times 0.2 \mathrm{~m} \times 0.3 \mathrm{~m}$
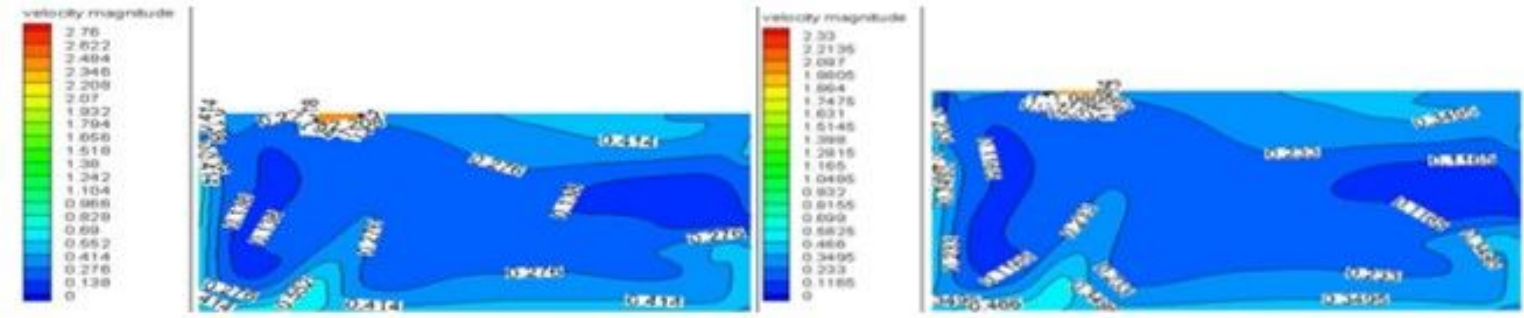

(e) size of indoor unit is $0.5 \mathrm{~m} \times 0.25 \mathrm{~m} \times 0.4 \mathrm{~m}$

(f) size of indoor unit is $0.5 \mathrm{~m} \times 0.3 \mathrm{~m} \times 0.5 \mathrm{~m}$

Figure 5

cloud pictures of velocity distribution at the section $z=1.8 \mathrm{~m}$ 


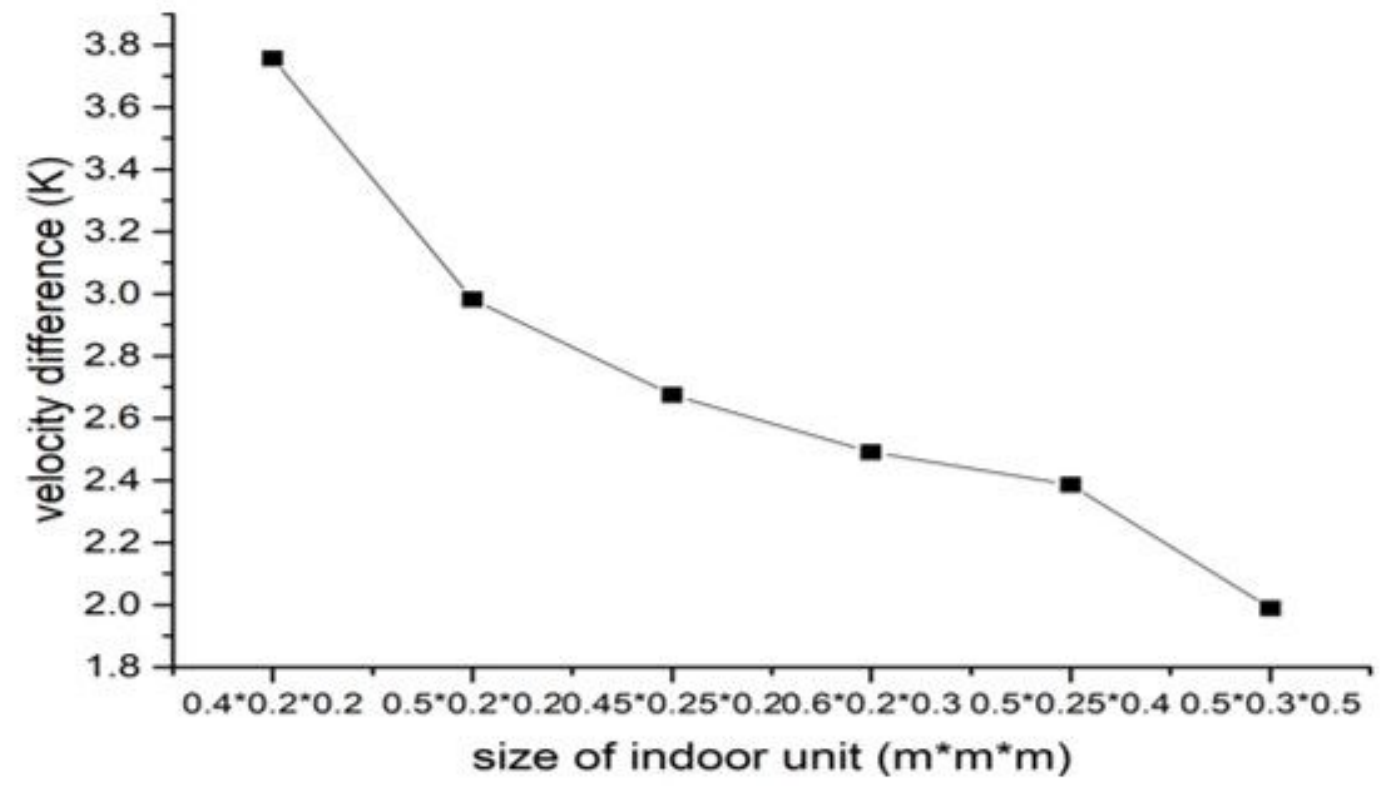

Figure 6

line diagram of velocity difference at the section $z=1.8 \mathrm{~m}$ 